\title{
UAB
}

Universitat Autònoma

de Barcelona

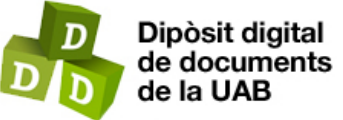

This is the accepted version of the article:

De Linares Fernández, Concepción; Alcázar, Purificación; Valle, Ana M.; [et al.]. «Parietaria major allergens vs pollen in the air we breathe». Environmental research, Vol. 176 (September 2019), art. 108514. DOI 10.1016/j.envres.2019.05.045

This version is avaible at https://ddd.uab.cat/record/215786

under the terms of the (c) BY-NC-ND license 
This is an Accepted Manuscript of the article De Linares, C., Alcázar, P., Valle, A.M., de la Guardia, C.D. and Galán, C., 2019. Parietaria major allergens vs pollen in the air we breathe. Environmental

research, 176, 108514, available online at https://doi.org/10.1016/j.envres.2019.05.045 (C2019. This manuscript version is made available under the CC-BY-NC-ND 4.0 license.

\section{Parietaria major allergens vs pollen in the air we breathe}

Concepción De Linares ${ }^{\mathrm{a}}$, Purificación Alcázar ${ }^{\mathrm{b}}$, Ana M. Valle ${ }^{\mathrm{c}}$, Consuelo Díaz de la Guardia ${ }^{\mathrm{d}}$, Carmen Galán ${ }^{\mathrm{b}}$

${ }^{a}$ Unitat de Botànica and Institut de Ciència i Tecnologia Ambientals (ICTA). Universitat Autònoma de Barcelona, Bellaterra. Spain.

${ }^{\mathrm{b}}$ Department of Botany, Ecology and Plant Physiology, University of Córdoba, Spain

${ }^{c}$ Pharmacy service, Campus de la Salud Hospital, Granada, Spain

${ }^{\mathrm{d}}$ Department of Botany, University of Granada, Spain

*Corresponding author: Concepción De Linares. Current address: Unitat de Botànica. Edifici C. Universitat Autònoma de Barcelona, Bellaterra. Spain. Phone: (+34) 935814729; fax: (+34) 935811321; e-mail: concepcion.delinares@uab.cat.

Key words

Allergens, Par j 1, Par j 2, Urticaceae pollen, PM10, PM2.5, airborne pollution. 
ABSTRACT:

Background: Parietaria and Urtica are the genera from the Urticaceae family more frequent in Mediterranean and Atlantic areas. Moreover, both genera share pollination periods, and their pollen (of the main species) is so similar that there is no aerobiological evidence of the proportion of each of them in the airborne pollen identification, except in the case of $U$. membranacea. However, Parietaria is one of the most important causes of pollinosis and Urtica is not. Our aim is determine if airborne Urticaceae pollen concentrations show the aerodynamics of the two major allergens of Parietaria (Par j 1 and Par j 2) as well as the allergen distribution in the different-sized particles.

Methods: The air was sampled during the pollination period of Urticaceae using Hirst Volumetric Sampler and Andersen Cascade Impactor in two cities of Southern Spain (Córdoba and Granada). The samples were analysed by the methodology proposed by the Spanish Aerobiology Network (REA) and the minimum requirements of the European Aeroallergen Society (EAS) for pollen, and by ELISA immunoassay for allergens.

Results: The patterns of airborne pollen and Par j 1-Par j 2 were present in the air during the studied period, although with irregular oscillations. Urticaceae pollen and Par j 1-Par j 2 allergens located in PM2.5 showed positive and significant correlation during the period with maximum concentrations (March to April).

Conclusion: Parietaria aeroallergens show similar pattern of Urticaceae airborne pollen. Urticaceae pollen calendar is as a good tool for allergy prevention. On the other hand, important concentrations of Par $\mathrm{j} 1$ and Par $\mathrm{j} 2$ were located in the breathable fraction (PM2.5), which could explain the asthmatic symptoms in the allergic population to Parietaria.

Keywords: Par j 1-Par j 2 allergens, Urticaceae pollen, Biological air quality, ELISA analysis 


\section{Introduction}

Allergic disorders constitute an important public health problem, which is increasing dramatically since the last decades. The pollen and spores are known to play an important role in respiratory allergies that appear especially during the flowering periods of plants. In Europe is estimated that the prevalence of pollen allergy affects up to $40 \%$ of the allergic population (D'Amato et al., 2007).

Urticaceae is a family of dicotyledonous plants with more than 1800 species. The better represented genera in the Mediterranean area are Parietaria L. and Urtica L. Both are wind-pollinated weed that are commonly found in the countryside and urban areas, growing on walls and soils with high nitrogen content. Moreover, the flowering of these genera is overlapped in time, beginning in winter and, in the case of Parietaria, being extended until autumn. Because pollen from different genera are similar under light microscopy (spheroidal, psilate and triporate), except for Urtica membranacea with smaller and periporate pollen, the pollen calendars are always displayed with the name of Urticaceae pollen type.

However, the clinical significance of these genera is different. Parietaria constitute the third most sensitizing allergen source after mites and grass pollens in South-East France (Charpin, 2000) and one of the main causes of asthma and rhinitis in Spain and Italy (D'Amato \& Liccardi 1994; Alergológica 2005). On the contrary, Urtica pollen displays little allergenic activity. Bousquet et al. (1986), Vega-Maray et al. (2006a) and Tiotiu et al (2016) confirmed the absence of cross-reactive antigens between Parietaria and Urtica pollen grains and concluded the lowest allergy risk of this last genus to induce diseases.

The first proteomic map of Parietaria pollen shows that the $36 \%$ of the total proteins correspond to allergens (Barranca et al., 2010). The major allergens isolated and characterized are Par j 1 and Par j 2 with $\operatorname{IgE}$ of $95 \%$ and $82 \%$, respectively. Both are two small non-specific lipid transfer protein (LTP) and present a conserved structure (Colombo et al., 1998). On the other hand, two minor allergens have been isolated and characterized: Par j 3 is a profilin protein (Asturias et al., 2004) and Par j 4 (Pj CBP) is characterized as Calcium-Binding Protein (Bonura et al., 2008).

In the last two decades, the Aerobiology focus the research on both, airborne pollen behaviour and aeroallergens (i.e. Moreno-Grau et al., 2006; De Linares et al., 2010; Jato et al., 2010; Galán et al., 2013; Buters et al. 2012, 2015; Alcázar et al. 2015; Plaza et al. 2016a, 2017). Knowledge on the dynamic of these particles is contributing to major information on airborne biological pollution. Several methods have been used for aeroallergen detection, such as Cyclone collector (i.e. Moreno-Grau et al., 2006; De Linares et al., 2014; Plaza et al 2016a; 2016b), Andersen cascade impactor (i.e. Schäppi et al., 1996; De Linares et al., 2007) or Chemvol ${ }^{\circledR}$ high-volume cascade Impactor (Buters et al. 2008; Albertini et al 2013; Galán et al 2013). Comparable results have been observed when comparing different samplers in the same place and years, i.e. Cyclone collector and Chemvol® high-volume cascade impactor in Córdoba (Plaza et al 2017). These studies have also shown similar dynamic between airborne pollen and aeroallergen but with discrepancies when exposition to different external events.

In the same way, there has been an increased interest in determining the size-fractions particles where these allergens are airborne (De Linares et al 2010; Esposito et al 2012; Buters et al 2012). Knowing that the Environmental Protection Agency (EPA) has determined that particles are classified in two size categories based on their penetration capacity into the lung as either: PM10 as particulate matter with an aerodynamic diameter of $10 \mu \mathrm{m}$ and PM2.5 as fine particulate matter with an aerodynamic diameter of $2.5 \mu \mathrm{m}$ (Esworthy, 
2013), a comparison of allergen load of these two categories could reveal the different clinical symptoms that provoke these particles.

The main goal of this paper was to study the behaviour of Urticaceae pollen and the two major Parietaria allergens, Par j 1 and Par j 2, in Southern Spain (Córdoba and Granada). The specific goals have been to determine if the airborne Urticaceae pollen concentrations show the aeroallergens dynamics and study the allergen distribution in different-sized particles to establish whether this distribution could be related with the allergy symptoms.

\section{Materials and methods}

\subsection{Area of study}

The aerobiological study was carried out in two cities of Southern Spain (Córdoba and Granada). The aerobiological station of Córdoba $\left(37^{\circ} 50^{\prime} \mathrm{N}, 04^{\circ} 45^{\prime} \mathrm{W} ; 123 \mathrm{~m}\right.$.a.s.l.) is situated in the University of Córdoba in the north-eastern part of the city, while the station of Granada is localized in the University of Granada in the city centre $\left(37^{\circ} 11^{\prime} \mathrm{N}, 03^{\circ} 35^{\prime} \mathrm{W} ; 685\right.$ m.a.s.1.). Although the climate in both cities is Mediterranean (characterized by moderate annual temperature and summer drought), it presents important oscillations in temperature (summer-winter and day-night).

The genera of Urticaceae family present in Córdoba and Granada are Urtica and Parietaria (Castroviejo et al. 1993; Blanca et al. 2009). U. dioica L., U. urens L. and P. judaica L. are present in both cities while $U$. membranacea Poir. in Lam. only in Córdoba and P. mauritanica L. and P. lusitanica L. only in Granada. Although the flowering start of these species is variable, their flowering periods are usually overlapped. According to the Spanish handbooks of plants (Castroviejo et al. 1993; Blanca et al. 2009), the flowering start of $U$. urens occurs in January, U. membranacea and P. lusitanica in February, P. judaica and $P$. mauritanica in March, and U. dioica in April.

\subsection{Sampling of Airborne Pollen and Allergens}

For this study, airborne pollen behaviour was performed during the period 1993-2016. The monitoring was realized with a volumetric Hirst type Spore Trap (Hirst 1952). This collector was designed specifically for pollen, spores, and other particles suspended in the air, with an aspiration of $10 \mathrm{~L} / \mathrm{min}$, comparable with the respiration of an average adult human.

Hirst samplers were placed at 22-23m above ground level. The counting method was that recommended by the Spanish Aerobiology Network, REA (Galán et al. 2007) and the minimum requirements of the European Aerobiology Society, EAS (Galán et al. 2017a). Terminology used in this paper follows the International Association for the Aerobiology (IAA) and EAS recommendations (Galán et al., 2017b). The daily pollen data are expressed as daily average of pollen per cubic metre of air (pollen $/ \mathrm{m}^{3}$ ). In this study, we analyse the data expressed in daily pollen and Annual Pollen Integral (APIn).

$U$. membranacea have a pollen type different from that of other Urticaceae species. The former has polipantoporate pollen with a smaller diameter of 9-12 $\mu \mathrm{m}$ while the others have triporate pollen with a diameter of 14-19 $\mu \mathrm{m}$ (Trigo et al 2008). In this study, only the dynamics of the Urticaceae pollen type was taken into account. 
The aeroallergens were studied through a temporal study considering the years from 2006 to 2009 in the aerobiological station of Córdoba and a spatial study analysing the year 2006, in two cities (Córdoba and Granada). In both cases a cascade impact collector was used (Andersen 1958). The sampling took place during the middle hours of the day when pollen concentrations are highest (between 12 and 17h) (Díaz de la Guardia et al. 1998; Galán et al 2000). These collectors distribute the particles in different stages of sizefractions. The air flow through the impactor is controlled by a pump that draws in air at $30 \mathrm{~L} / \mathrm{min}$ (Lanzoni SPS 3001, Italy). The size discrimination of the particles is possible by the variation in the air velocity, which is led sequentially through a series of fibreglass Whatman ${ }^{\circledR}$ filters (Glass microfibre filters; type: GF/A) of descending pore size, this increasing the air velocity from the first stage to the last. The largest particles are deposited at the first stages while the smallest pass through the collector until being stopped by the correspondingly fine filter (Andersen 1958).

The samples were analysed by an indirect ELISA (De Linares et al. 2007). For each filter, 4 circular replicates (diameter $0.5 \mathrm{~cm}$ ) were taken on a radial pattern. As a control, 4 replicates of 1 filter with no impact were used. The filters were submerged in $125 \mu \mathrm{L}$ phosphate-buffered saline (PBS, pH 7.4) in microplate wells for $20 \mathrm{~h}$ at room temperature. The discs were removed and the wells cleaned with PBSTW (0.3\% Tween 20). After blocking during $1 \mathrm{~h}$ at $37^{\circ} \mathrm{C}$ with $200 \mu \mathrm{L} /$ well of PBS containing $1 \%$ bovine serum albumin (Sigma, St. Louis, Mo., USA) and 0.3\% Tween 20. After 3 washes with $200 \mu$ L PBS-TW (0.3\% Tween 20), $125 \mu \mathrm{L}$ horseradish peroxyidase (Polyclonal Swine Anti-Rabbit Immunoglobulins; Dako Cytomation, Glostrup, Denmark) diluted in PBS at a concentration of 1: 1,000, was added and incubated in the same conditions. Further washes were carried out by incubating at room temperature and in darkness with $125 \mu \mathrm{L}$ O-phenylenediamine (OPD; Sigma, St. Louis, Mo., USA). This reaction was stopped by adding $50 \mu \mathrm{L}$ of $\mathrm{HCl} 3 \mathrm{~N}$. The results in all cases are expressed in nanograms of allergen per cubic metre. Par j 1-Par j 2 allergens were quantified using polyclonal antibody (Bial-Aristegui, Spain), which were isolated in the same fraction and identified by the fingerprinting of the peptide (Arilla et al., 2006). The standard curve was drawn from dilutions of Par j 1-Par j 2 allergens purified from $P$. judaica pollen extract by affinity chromatography (Bial-Aristegui, Spain; Arilla et al., 2006).

For a reliable comparison of the results for the two samples of two cities, these collectors functioned adjacently to Hirst samplers on the same timetable. The results in all cases are expressed in nanograms of allergen per cubic metre of air $\left(\mathrm{ng} / \mathrm{m}^{3}\right)$.

\subsection{Meteorological data}

Daily series of Temperature (maximum, mean, and minimum), Precipitation and mean Related Humidity were used. Data were provided by the Andalusia Network of Agroclimatic Information (RIAA).

\subsection{Statistical analysis}

The reproducibility of ELISA technique was determined by mean the coefficient of variance percentage $(\% \mathrm{CV})$ being calculated as the standard deviation/mean $\times 100.30$ replicates in each city and year were used. In the case of Córdoba, the CV ranges from $8.33 \%$ to 6.53 and in Granada, $6.65 \%$. 
Spearman's correlation coefficients between daily data of Urticaceae pollen, Par j 1-Par j 2 allergen, allergen in Pm10 and PM2.5, and meteorological parameters were calculated during the allergen studied period. This analysis was carried out by using the SPSS version 19.0.

\section{Results}

\subsection{Airborne pollen vs. aeroallergens}

The meteorological parameters during the studied period were examined in each area (Table 1). In Córdoba, a warmer and rainier climate is observed $\left(16.9^{\circ} \mathrm{C}, 553.7 \mathrm{~mm}\right)$ than in Granada, with a colder and drier climate $\left(15.2^{\circ} \mathrm{C}, 267.4 \mathrm{~mm}\right)$.

Figure 1 shows average concentration of the Urticaceae airborne pollen during 24 years (1993-2016) and the annual patterns during the studied period. This pollen type is presented in the air throughout the year showing its maximum pollination in winter and spring in both cities. Córdoba registered a lower concentration than Granada, and showed an explosive increase in its concentrations at the beginning of spring. Instead in Granada, the higher concentrations were registered during end of spring.

Regarding the years with pollen and allergen detection, the four year aerobiological behavior in Córdoba followed similar dynamics to the average 1993-2016 for pollen (Figure 1). 2009 presented the longest pollen season (256 days) but the lowest Annual Pollen Integral (APIn) (1343 pollen $/ \mathrm{m}^{3}$ ), while 2006 presented the shortest season (134 days) and 2008 the highest APIn (3306 pollen $\left./ \mathrm{m}^{3}\right)$. The peak day pollen concentration was higher in $2006\left(400\right.$ pollen $\left./ \mathrm{m}^{3}\right)$ than the others years (ranging from 151 to $53 \mathrm{pollen} / \mathrm{m}^{3}$ ) (Table 1).

In Granada, the Urticaceae airborne pollen concentration recorded during 2006 followed similar patterns to the average 1993-2016, as in Córdoba, this year registered higher pollen concentrations than others years (Figure 1).

The comparative study of the two cities during the same year (2006) shows that the APIn in Córdoba was 2108 pollen $/ \mathrm{m}^{3}$, registering the peak day on 2st April (400 pollen $\left./ \mathrm{m}^{3}\right)$. In Granada, this pollen type registered higher APIn (5957 pollen $/ \mathrm{m}^{3}$ ) and was presented in the air during more time (338 days) than on Córdoba (134 days), despite peak day was registered two days before with lower concentration (31th March, 194 pollen $/ \mathrm{m}^{3}$; Table 1).

The Spearman correlation test between Urticaceae pollen concentrations and meteorological variables during allergen study period (Table 2) showed significant and negative correlations with the temperature in both cities (except 2007 in Córdoba). On the other hand, relative humidity presented significant and positive correlation in 2006 and 2009 in Córdoba, and also during 2006 in Granada.

The aeroallergen study during the four years in Córdoba showed fluctuation in the analysed years (Table 1). The Allergen Season Integral (ASIn) and peak allergenic concentrations recorded differences; while in 2007 was detected $23016.9 \mathrm{ng} / \mathrm{m}^{3}$ of Par j 1-Par $\mathrm{j} 2$ in the 118 analysed days, in 2008 was detected 13037.8 $\mathrm{ng} / \mathrm{m}^{3}$ during the 170 analysed days. In the case of peak allergen days, while the highest concentration were detected in 2007 (February 27th), reaching the $856.1 \mathrm{ng} / \mathrm{m}^{3}$; the lowest occurred in 2008 (June 12th) with $389.8 \mathrm{ng} / \mathrm{m} 3$. Only 2009 and 2008 registered moments where airborne allergens were not detected (18 and 7 days, respectively). Comparing Córdoba and Granada during 2006, the peak day in Córdoba occurred on March 29th with $450.3 \mathrm{ng} / \mathrm{m}^{3}$, while in Granada occurred on May 9th, with $369.6 \mathrm{ng} / \mathrm{m}^{3}$. 
The aeroallergen dynamic of Par j 1-Par $\mathrm{j} 2$ in both cities was characterized by its continued presence during the studied period, although with irregular oscillations (Figure 1). In the case of Córdoba, when Urticaceae pollen registered the highest concentrations, aeroallergen behaviour was similar to pollen. However, before and after pollen season, allergen load was detected. On the other hand, Granada registered two allergen periods with different concentrations: 1st February to 30th April, with low levels but with similar dynamic with airborne pollen; and 1st May to 30th June, with high allergen concentrations and low pollen (Figure 1).

Results for the Spearman correlation test around the studied period are showed in Table 2. In Córdoba positive and significant correlation between Urticaceae pollen and Par j 1-Par j 2 during 2007 and 2008 were registered ( 0.225 and $0.212 ; \mathrm{p}<0.05$, respectively), but not in 2006 and 2009. In relation with the meteorological variables, aeroallergens showed significant correlation with mean and minimum temperature $(2007,2008$, and 2009).

The spatial study shows that during 2006 non-significant correlation was observed between aeroallergens and pollen. However, if we analyse the period with maximum pollen concentration in both cities (1st March-30th April in Córdoba and 1st February-30th April in Granada), the correlation were positive and significant $(0.440 ; p<0.05$ and $0.283 p<0.01$, respectively). In relation with the meteorological variables, allergens concentrations showed significant correlation with maximum temperature in Granada.

\subsection{Airborne allergens in different-size particles}

The distribution of Par j 1-Par $\mathrm{j} 2$ allergen according to the particle sizes showed that the stage with larger particles (stage 1) registered the lower concentration of allergens (Table 3), lower than 10.2\%. In Córdoba the highest allergens concentrations were localized in the different stages depending of the studied year. Comparing 2006 in both cities, in Córdoba the highest concentration (25.1\%) were registered in stage 3 and in Granada in the stage $6(35.6 \%)(<1.1 \mu \mathrm{m})$.

According to EPA classification, the results obtained showed that the highest allergen load was localized in PM 2.5 in the both cities (ranging to $67.9 \%$ to $39.3 \%$ in Córdoba, and $72.1 \%$ in Granada during 2006), except in 2009 that the result was opposite, with higher concentrations in PM10.

Correlation analysis between allergen load (PM10 and PM2.5), airborne pollen concentration and meteorological variables are showed in Table 2 . The results showed similar correlations when comparing aeroallergen with pollen, i.e., PM 2.5 showed significant positive correlations with Urticaceae pollen, while PM10 not. This analysis in relation with meteorological variables obtained non-significant results.

\section{Discussion}

\subsection{Dynamics of Airborne particles related with Urticaceae pollen}

One of the main goals when monitoring pollen and spores is to know the allergen exposition in the air to develop successful strategies for protecting human health and improve the quality of life of allergic patients. At the end of the 1990s, the studies of aeroallergens, based on immunological analysis, have been recognized as a good bio-indicator of the allergens presence and as a good tool for improving prevention mechanisms in allergic patients (Cecchi, 2013).

In this study, the daily average of Urticaceae pollen concentration (1993-2016) shows a constant presence throughout the year in both cities, although the highest levels are recorded between late winter and early 
spring. . Both studied cities are characterized by showing variability in interannual behaviour. E.g. Córdoba registered average autumn concentration of 23 and 21 pollen $/ \mathrm{m}^{3}$ during 1996 and 2000 respectively, while in the other years were ranging 6 to 1 pollen $/ \mathrm{m}^{3}$. The same phenomenon was registered in Granada where the average autumn concentration was 11 pollen $/ \mathrm{m}^{3}$ during 1997 and 2001, while in the other years were ranging 4 to 1 pollen $/ \mathrm{m}^{3}$. These significant average concentrations have contributed to provoke that the mean pollen calendar show two peaks (spring and autumn) while it is not shown for the allergens during the studied years. In the other hand, 2006 has been characterized by an explosive flowering in few days and a peak day of 400 pollen $/ \mathrm{m}^{3}$ in Córdoba and $194 \mathrm{pollen} / \mathrm{m}^{3}$ in Granada. This variable interannual and intraannual behavior has been observed in previous years in the same cities (Galán et al., 2000; Díaz de la Guardia et al., 1998) and in other regions of Mediterranean area (Belmonte and Roure, 1991; Trigo et al., 1996; Belmonte et al., 1999) due to the humidity is a determinant factor in the Urticaceae pollen concentration. In fact, the correlation between pollen and relative humidity in this study was positive and significant in both cities. On the other hand, the significant negative correlation with daily temperature in both cities could be due to drought stress, because the increased of temperature provokes withering of these plants.

Many studies have indicated that airborne pollen and allergens load have parallel dynamics with significant correlations during the period of maximum pollination (Spieksma et al. 1995, Schäppi et al. 1996, Spieksma and Nikkelss 1999, De Linares et al 2010; Buters et al., 2012). In the case of Parietaria allergens, significant correlations were obtained in Córdoba during 2007 and 2008 for all period studied while in 2006 (as occurred in Granada) the significant correlation was obtained during the period with maximum pollen concentration. These results coincide with another study on Parietaria allergens in Spain (Jato et al., 2010) with a low but positive correlation between Par j 1-Par j 2 and Urticaceae pollen in Cartagena (Southeaster Spain) and Ourense (Northwester Spain).

Although during March to April high values of pollen and allergens were reached, in May and June the allergen concentrations were higher than airborne pollen. With the botanical information obtained in the Spanish handbooks of plants (Castroviejo et al. 1993; Blanca et al. 2009), it could speculate that the high levels of Urticaceae pollen during March and April in both cities probably are due to overlap the blooming of Urtica and Parietaria plants. After these months, the flowers of Urtica wither while Parietaria continues to flower (especially $P$. judaica, which continues until the end of autumn) showing the real pollination of Parietaria (more low than Urtica) and high allergen load.

The temporal study realized in Cordoba during the four years showed that the years with maximum allergen concentrations, the pollen concentrations were lower and vice versa. 2009 was the year with higher allergens concentrations but lower pollen (Table 1). This year registered the more extreme meteorological conditions, with the highest temperatures, and the lowest precipitation and relative humidity of the period 2006-2009. As Chen et al. (2016) indicated, the pollen allergens could be associated with stress responses and metabolic events during pollen development. Although more studies are needed, perhaps the release of the Parietaria allergens is conditioned to stress, registering this significant increase levels in 2009.

\subsection{Parietaria airborne allergens in different particles sizes}

The allergen load in Andersen cascade Impactor showed differences in the distribution of these particles. Except in Córdoba during 2009, the maximum allergen concentrations were detected in PM 2.5. Several 
studies have speculated that the pollen grains can release allergens before germination, appearing smaller biological particles with equal or greater allergenicity (Suarez-Cervera et al., 2003; Vega-Maray et al., 2006b; De Linares et al. 2007; Prado et al., 2015). The present study has supported these results and has classified the particles according to size and to EPA categories. The major concentrations of aeroallergens registered have an aerodynamic size that can easily penetrate the lower respiratory zone and provoke asthmatic symptoms almost immediately. It could explain the high percentage of asthmatic symptoms in the patients sensitized to Parietaria. I.e. in Italy and Spain more than $50 \%$ of patients sensitized suffer asthma with severe bronchial hyper-responsiveness (D'Amato et al 2007 and Alergólogica 2005, respectively).

The analysis protocol carried out in this study has been focused to simulate the mucosal surface of the human tract respiratory, using phosphate-buffered saline (PBS, pH 7.4) as hydration method. Given that the allergens are located in the interior of the pollen grains (Casas et al., 1996; Vega-Maray et al., 2006b), if this pollen has not germinated during the hydration process and released proteins into the wells of the microplate, the primary antibody is incapable of detecting the existence of allergens, and therefore less activity is detected (De Linares et al. 2007). The use of saline buffer shows that in natural conditions, the human respiratory tract is exposed to allergens located in different sizes particles. If the allergen concentration in PM10 particles is compared with PM 2.5, this study shows that there is an important allergen load located in particles low than $2.5 \mu \mathrm{m}$ that can easily penetrate the lower respiratory zone and provoke asthmatic symptoms almost immediately.

Spearman correlation analysis have shown a positive and significant correlation between Urticaceae pollen vs Par j 1- Par j 2 and PM 2.5 in all studied period, except in 2009. This year, Córdoba registered the lowest precipitations and relative humidity of this period (2006-2009) and this situation could affect the allergen release per pollen.

In conclusion, the Urticaceae airborne pollen shows similar pattern of Parietaria allergens in the atmosphere. For this reason, the Urticaceae pollen calendar is a good tool for allergy prevention. On the other hand, important Par $\mathrm{j} 1$ and Par $\mathrm{j} 2$ concentrations are located in the breathable fraction, which could explain the asthmatic symptoms in the Parietaria allergic population.

\section{Acknowledgements}

The authors wish to thank the Ministry of Science and Technology I+D+I "CGL2006-1648-CO3-02" and FENOMED for financing this study. Also the Andalusian Government for "RNM 0110 PAIDI".

\section{References}

Albertini R., Ugolotti M., the HIALINE team, 2013. The European project HIALINE (Health Impacts of Airborne Allergen Information Network): results of pollen and allergen of Betula monitoring in Parma (2009). Review Allergy and Clinical Immunology 23, 14-20.

Alcázar P., Galán C., Torres C., Domínguez-Vilches E., 2015. Detection of airborne allergen (Pla a 1) in relation to Platanus pollen in Córdoba, South Spain. Annals of Agricultural and Environmental Medicine 22(1), 96-101. 
Alergológica 2005. Factores epidemiológicos, clínicos y socioeconómicos de las enfermedades alérgicas en España en 2005. SEAIC. Madrid; 2006

Andersen A.A., 1958. New sampler for the collection, sizing, and enumeration of viable airborne particles. Journal of Bacteriology 76(5), 471.

Arilla M.C., González-Rioja R., Ibarrola I., Mir A., Monteseirin J., Conde. J., Martínez A., Asturias J.A., 2006. A sensitive monoclonal antibody-based enzyme-linked immunosorbent assay to quantify Parietaria judaica major allergens, Par j 1 and Par j 2. Clinical Experimental Allergy 36(1), 8793.

Asturias J.A., Ibarrola I., Eseverri J.L., Arilla M.C., Gonzalez-Rioja R., Martínez A., 2004. PCR-based cloning and immunological characterization of Parietaria judaica pollen profilin. Journal of Investigational Allergology \& Clinical Immunology 14(1), 43-48.

Barranca M., Fontana S., Taverna S., Duro G., Zanella-Cleon I., Becchi M., De Leo G., Alessandro R., 2010. Proteomic analysis of Parietaria judaica pollen and allergen profiling by an immunoproteomic approach. Biotechnology Letters 32(4), 565-570.

Belmonte J., Roure J.M., 1991. Characteristics of the aeropollen dynamics at several localities in Spain. Grana 30, 364-372.

Belmonte J., Canela M., Guardia R., Guardia R.A., Sbai L., Vendrell M., Alba F., Alcázar P., Cabezudo B., Gutiérrez M., Méndez J., Valencia R., 1999. Aerobiological dynamics of the Urticaceae pollen in Spain, 1992-98. Polen 10, 79-91.

Blanca G., Cabezudo B., Cueto M., Fernández López C., Morales Torres C., 2009. Flora vascular de Andalucía oriental. Vol. 3: Rosaceae- Lentiburiaceae. Consejería de Medio Ambiente, Junta de Andalucía, Sevilla, Spain.

Bonura A., Gulino L., Trapani A., Di Felice G., Tinghino R., Amoroso S., Geraci D., Valenta R., Westritschnig K., Scala E., Mari A., Colombo P., 2008. Isolation, expression and immunological characterization of a calcium-binding protein from Parietaria pollen. Molecular Immunology 45(9), 2465-2473.

Bousquet J., Hewitt B., Guerin B., Dhivert H., Michel F.B., 1986. Allergy in the Mediterranean area II: cross-allergenicity among Urticaceae pollens (Parietaria and Urtica). Clinical Experimental Allergy 16(1), 57-64.

Buters J.T., Kasche A., Weichenmeier I., Schober W., Klaus S., Traidl-Hoffmann C., Menzel A., HussMarp J., Krämer U., Behrendt H., 2008. Year-to-year variation in release of Bet v 1 allergen from birch pollen: evidence for geographical differences between West and South Germany. International Archives of Allergy and Immunology 145(2), 122-130.

Buters J.T., Thibaudon M., Smith M., Kennedy R., Rantio-Lehtimäki A., Albertini R., Reese G., Weber B., Galán C., Brandao R., Antunes C.M., Jäger S., Berger S., Celenk S., Grewling L., Jackowiak B., Sauliene I., Weichenmeier I., Pusch G., Sarioglu H., Ueffing M., Behrendt H., Prank M., Sofiev M., Cecchi L., The HIALINE working group., 2012. Release of Bet v 1 from birch pollen from 5 European countries. Results from the HIALINE study. Atmospheric Environment 55, 496-505.

Buters J.T., Prank M., Sofiev M., Pusch G., Albertini R., Annesi-Maesano I., Antunes C., Behrendt H., Berger U., Brandao R., Celenk S., 2015. Variation of the group 5 grass pollen allergen content of 
airborne pollen in relation to geographic location and time in season. Journal of Allergy and Clinical Immunology 136(1), 87-95.

Casas C, Márquez J., Suárez-Cervera M., Seoane-Camba J.A., 1996. Immunocytochemical localization of allergenic proteins in Parietaria judaica L. (Urticaceae) pollen grains. European Journal of Cell Biology 70(2), 179-188.

Castroviejo S., Aedo C., Cirujano S., Laínz M., Montserrat P., Morales R., Muñoz Garmendia F., Navarro C., Paiva J., Soriano C.. (eds.), 1993. Flora ibérica III. Real Jardín Botánico, CSIC, Madrid, Spain.

Cecchi L., 2013. From pollen count to pollen potency: the molecular era of aerobiology. European Respiratory Journal 42(4), 898-900.

Charpin D., 2000. Epidemiology of ciprés allergy. Allergy Immunology 32, 83-85.

Chen M., Xu J., Devis D.L., Shi J., Ren K., Searle I., Zhang D., 2016. Origin and functional prediction of pollen allergens in plants. Plant Physiology 172:341-357.

Colombo P., Kennedy D., Ramsdale T., Costa M.A., Duro G., Izzo V., Salvadori S., Guerrini R., Cocchiara R., Marisola M.G., Wood, S., Geraci, D., 1998. Identification of an immunodominant IgE epitope of the Parietaria judaica major allergen. The Journal of Immunology 160(6), 2780-2785.

D’Amato G., Liccardi G., 1994. Pollen-related allergy in the European Mediterranean area. Clinical Experimental Allergy 24, 210-219.

D’Amato G., Cecchi L., Bonini S., Nunes C., Annesi-Maesano I., Behrendt H., Liccardi G., Popoc T., Van Cauwenberge P., 2007. Allergenic pollen and pollen allergy in Europe. Allergy 62(9), 976-990.

De Linares C., Nieto-Lugilde D., Alba F., Díaz de la Guardia C., Galán C., Trigo M.M., 2007. Detection of airborne allergen (Ole e 1) in relation to Olea europaea pollen in S Spain. Clinical Experimental Allergy 37(1), 125-132.

De Linares C., Díaz de la Guardia C., Nieto Lugilde D., Alba F., 2010. Airborne study of grass allergen (Lol p 1) in different-sized particles. International Archives of Allergy and Immunology 152(1), 49-57.

De Linares C., Postigo I., Belmonte J., Canela M., Martínez J., 2014. Optimization of the measurement of outdoor airborne allergens using a protein microarrays platform. Aerobiologia 30(3), 217-227.

Díaz de La Guardia C., Alba F., Girón F., Sabariego S., 1998. An aerobiological study of Urticaceae pollen in the city of Granada (S. Spain): Correlation with meteorological parameters. Grana 37(5), 298304.

Esworthy R., 2013. Air quality: EPA's 2013 changes to the particulate matter(PM) standard. Congressional Research Service, 7-5700.

Esposito V., Lucariello A., Savarese L., Cinelli M.P., Ferraraccio F., Bianco A., De Luca A., Mazzarella G., 2012. Morphology changes in human lung epithelial cells after exposure to diesel exhaust micron sub particles (PM 1.0) and pollen allergens. Environmental Pollution 171, 162-167.

Galán C., Alcázar P., Cariñanos P., Garcia H., Domínguez-Vilches E., 2000. Meteorological factors affecting daily Urticaceae pollen counts in southwest Spain. International Journal of Biometeorology 43(4), 191-195. 
Galán C., Cariñanos P., Alcázar P., Domínguez E., 2007. Manual de Calidad y Gestión de la Red Española de Aerobiología [Quality Manual and Management Spanish Aerobiology Network]. Servicio de Publicaciones de la Universidad de Córdoba, Spain.

Galán C., Antunes C., Brandao R., Torres C., Garcia-Mozo H., Caeiro E., Ferro R., Prank M., Sofiev M., Albertini R., Berger U., Cecchi L., Celenk S., Grewling Ł., Jackowiak B., Jäger S., Kennedy R., Rantio-Lehtimäki A., Reese G., Sauliene I., Smith M., Thibaudon M., Weber B., Weichenmeier I., Pusch G., Buters J.T.M.B. on behalf of the HIALINE working group., 2013. Airborne olive pollen counts are not representative of exposure to the major olive allergen Ole e 1. Allergy 68(6), 809-812.

Galán C., Smith M., Thibaudon M., Frenguelli G., Oteros J., Gehrig R., Berger U., Clot B., Brandao R., the EAS QC Working Group., 2017a. Pollen monitoring: minimum requirements and reproducibility of analysis. Aerobiologia 30(4), 385-395.

Galán C., Ariatti A., Bonini M., Clot B., Crouzy B., Dahl A., Fernández-González D., Frenguelli G., Gehrig R., Isard S., Levetin E., Li D.W., Mandrioli P., Rogers C.A., Thibaudon M., Sauliene I., Skjoth C., Smith M., Sofiev M., 2017b. Recommended terminology for aerobiological studies. Aerobiología 33(3), 293-295. doi 10.1007/s10453-017-9496-0

Hirst J.M., 1952. An automatic volumetric spore-trap. Ann Appl Biol 39(2), 257-265.

Jato V., Rodríguez-Rajo F.J., González-Parrado Z., Elvira-Rendueles B., Moreno-Grau S., Vega-Maray A., Fernández-González D., Asturias J.A., Suárez-Cervera M., 2010. Detection of airborne Par j 1 and Par j 2 allergens in relation to Urticaceae pollen counts in different bioclimatic areas. Annals of Allergy, Asthma \& Immunology 105(1), 50-56.

Moreno-Grau S., Elvira-Rendueles B., Moreno J., García-Sánchez A., Vergara N., Asturias J.A., Arilla M.C., Ibarrola I., Seoane-Camba J.A., Suárez-Cervera M., 2006. Correlation between Olea europaea and Parietaria judaica pollen counts and quantification of their major allergens Ole e 1 and Par j 1-Par j 2. Annals of Allergy, Asthma \& Immunology 96(6), 858-864.

Plaza M.P., Alcázar P., Hernández-Ceballos M.A., Galán C., 2016a. Mismatch in aeroallergens and airborne grass pollen concentrations. Atmospheric Environment 144, 361-369.

Plaza M.P., Alcázar P., Galán C., 2016b. Correlation between airborne Olea europaea pollen concentrations and levels of the major allergen Ole e 1 in Córdoba, Spain, 2012-2014. International Journal of Biometeorology 60, 1841-1847.

Plaza M.P., Alcázar P., Velasco-Jiménez M.J., Galán C., 2017. Aeroallergens: a comparative study of two monitoring methods. Aerobiologia 33, 363-373.

Prado N., De Linares C., Sanz M.L., Gamboa P., Villalba M., Rodríguez R., Batanero E., 2015. Pollensomes as natural vehicles for pollen allergens. The Journal of Immunology 195(2), 445-449.

Schäppi G.F., Monn C., Wüthrich B., Wanner H.V., 1996. Analysis of allergens in ambient aerosols: Comparison of areas subjected to different levels of air pollution. Aerobiologia 12, 185-190.

Spieksma F.T.M., Nikkels A.H., Dijkman J.H., 1995. Seasonal appearance of grass pollen allergen in natural, pauci-micronic aerosol of various size fractions; Relationship with airborne grass pollen concentration. Clinical Experimental Allergy 25, 234-239. 
Spieksma F.T.M., Nikkels A.H., 1999. Similarity in seasonal appearance between atmospheric birch-pollen grains and allergen in paucimicronic, size-fractionated ambient aerosol. Allergy 54, 235-241.

Suarez-Cervera M., Takahashi Y., Vega-Maray A., Seoane Camba J.A., 2003. Immunocytochemical localization of Cry j 1, the major allergen of Cryptomeria japonica (Taxodiaceae) in Cupressus arizonica and Cupressus sempervirens (Cupressaceae) pollen grains. Sexual Plant Reproduction $16,9-15$

Tiotiu A., Brazdova A., Longé C., Gallet P., Morisset M., Leduc V., Hilger C., Broussard C., Couderc R., Sutra J.P., Sénéchal, H., Poncet P. 2016. Urtica dioica pollen allergy: clinical, biological, and allergomics analysis. Annals of Allergy, Asthma \& Immunology 117(5): 527-534.

Trigo M.M., Cabezudo B., Recio M., Toro F.J., 1996. Annual, daily and dirunal variations of Urticaceae airborne pollen in Málaga (Spain). Aerobiologia 12(2), 85-90.

Trigo M.M., Jato V., Fernández D., Galán C., 2008. Atlas Aeropalinológico de España. Secretariado de Publicaciones de la Universidad de León, Spain,

Vega-Maray A.M., Fernández-González D., Valencia-Barrera R., Suárez-Cervera M., 2006a. Allergenic proteins in Urtica dioica, a member of the Urticaceae allergenic family. Annals of Allergy, Asthma \& Immunology 97(3), 343-349.

Vega-Maray A.M., Fernández-González D., Valencia-Barrera R., Suárez-Cervera M. 2006b. Detection and release of allergenic proteins in Parietaria judaica pollen grains. Protoplasma 228(1-3), 115-120. 
Table 1. Par j 1-Par j 2 allergens, Urticaceae pollen and meteorological parameters in Córdoba and Granada. Tmax (mean annual maximum temperature), Tmean (mean annual temperature), Tmin (mean annual minimum temperature), P (total annual rainfall), RH (mean annual Relative Humidity).

\begin{tabular}{|c|c|c|c|c|c|}
\hline & \multirow{2}{*}{\begin{tabular}{r||} 
Granada \\
2006
\end{tabular}} & \multicolumn{4}{|c|}{ Córdoba } \\
\hline & & 2006 & 2007 & 2008 & 2009 \\
\hline \multicolumn{6}{|l|}{ Par j 1-Par j 2 allergens } \\
\hline Peak (ng/m³) & 369,6 & 450,3 & 856,1 & 389,8 & 3494,7 \\
\hline Peak day & 9-May & 29-Mar & 27-Feb & 12-Jun & 11-Mar \\
\hline Analyzed days & 150 & 92 & 120 & 172 & 170 \\
\hline Days with allergen presence & 150 & 92 & 118 & 170 & 152 \\
\hline Allergen Integral & 21116,6 & 13459,6 & 23016,9 & 13037,8 & 18884,4 \\
\hline \multicolumn{6}{|l|}{ Urticaceae Pollen } \\
\hline Peak (pollen/m³) & 194 & 400 & 53 & 151 & 56 \\
\hline Peak day & 31-Mar & 2-Apr & 24-Mar & 13-Mar & 4-Apr \\
\hline Analyzed days & 365 & 351 & 364 & 358 & 349 \\
\hline Days with pollen presence & 338 & 134 & 205 & 235 & 256 \\
\hline Pollen Integral during period allergen studied & 4218 & 1764 & 1509 & 3037 & 1145 \\
\hline Annual Pollen Integral & 5957 & 2108 & 1843 & 3306 & 1343 \\
\hline \multicolumn{6}{|l|}{ Meteorological data } \\
\hline Tmax & 23,4 & 24,6 & 24,3 & 24,0 & 26,0 \\
\hline Tmean & 15,2 & 17,7 & 16,9 & 17 & 18,9 \\
\hline Tmin & 8,0 & 11,5 & 10,4 & 10,4 & 11,9 \\
\hline $\mathbf{P}$ & 267,4 & 553,7 & 521 & 660 & 436,4 \\
\hline RH & 71,0 & 65,2 & 62,6 & 62,3 & 56,4 \\
\hline
\end{tabular}


Table 2. Correlation coefficients for Urticaceae pollen, Par j 1-2 allergens, allergens in Pm 10 and PM 2.5, and meteorological factors over the total study period and during the Maximum Pollen Concentration of $2006{ }^{* *} \mathrm{p}<0.01 ;{ }^{*} \mathrm{p}<0.05$. Tmax (maximum temperature), Tmean (mean temperature), Tmin (minimum temperature), $\mathrm{P}$ (total rainfall), $\mathrm{RH}$ (mean Relative Humidity).

\begin{tabular}{|c|c|c|c|c|c|c|c|c|c|}
\hline & & & $\begin{array}{r}\text { Urticaceae } \\
\text { Pollen }\end{array}$ & Par j 1-Par j 2 & Tmax & Tmean & $\operatorname{Tmin}$ & $\mathbf{P}$ & $\mathbf{R H}$ \\
\hline \multirow{20}{*}{ 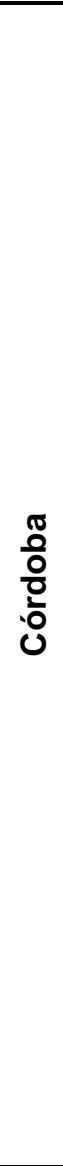 } & 2009 & Urticaceae Pollen & 1.000 & 0.089 & $-0.315^{\star *}$ & $-0.407^{* *}$ & $-0.353^{* *}$ & -0.109 & 0.173 \\
\hline & $(n=170)$ & Par j 1-Par j 2 & 0.089 & 1.000 & -0.133 & -0.146 & $-0.173^{*}$ & 0.220 & 0.110 \\
\hline & & PM 10 & 0.104 & $0.895^{\star \star}$ & $-0.164^{* *}$ & $-0.169 * *$ & $-0.180^{*}$ & 0.021 & 0.155 \\
\hline & & PM 2.5 & 0.041 & $0.844^{* *}$ & -0.129 & -0.138 & $-0.173^{*}$ & 0.063 & 0.089 \\
\hline & 2008 & Urticaceae Pollen & 1.000 & $0.212^{*}$ & $-0.243^{* *}$ & $-0.329^{* *}$ & $-0.418^{* *}$ & -0.129 & 0.039 \\
\hline & $(n=172)$ & Par j 1-Par j 2 & $0.212^{*}$ & 1.000 & 0.142 & $0.103^{*}$ & $0.209^{* *}$ & -0.027 & $0.08 \varepsilon$ \\
\hline & & PM 10 & 0.137 & $0.893^{* *}$ & $-0.150^{*}$ & $-0.179^{*}$ & $-0.191^{*}$ & -0.031 & -0.133 \\
\hline & & PM 2.5 & $0.225^{*}$ & $0.953^{* *}$ & 0.122 & $0.163^{*}$ & $0.163^{*}$ & -0.011 & -0.053 \\
\hline & 2007 & Urticaceae Pollen & 1.000 & $0.225^{*}$ & 0.024 & -0.022 & -0.113 & -0.172 & -0.037 \\
\hline & $(n=120)$ & Par j 1-Par j 2 & $0.225^{*}$ & 1.000 & -0.137 & -0.212 & $-0.247^{* *}$ & 0.052 & 0.033 \\
\hline & & PM 10 & 0.134 & $0.800^{* *}$ & -0.057 & -0.118 & $-0.200^{* *}$ & -0.066 & -0.074 \\
\hline & & PM 2.5 & $0.261^{*}$ & $0.870^{\star *}$ & $-0.192^{\star}$ & $-0.264^{\star *}$ & $-0.264^{* *}$ & 0.05 & $-0.12 \mathrm{c}$ \\
\hline & 2006 & Urticaceae Pollen & 1.000 & 0.145 & $-0.518^{* *}$ & $-0.576^{* *}$ & $-0.510^{* *}$ & 0.184 & 0.431 \\
\hline & $(n=91)$ & Par j 1-Par j 2 & 0.415 & 1.000 & -0.015 & -0.013 & -0.078 & -0.046 & -0.064 \\
\hline & & PM 10 & 0.060 & $0.849^{* *}$ & 0.104 & 0.121 & 0.083 & 0.041 & -0.141 \\
\hline & & PM 2.5 & 0.178 & $0.917^{* *}$ & -0.098 & 0.108 & -0.173 & -0.094 & -0.005 \\
\hline & MPC 2006 & Urticaceae Pollen & 1.000 & $0.440^{*}$ & 0.37 & 0.357 & -0.071 & $-0.464^{* *}$ & $0.562 *$ \\
\hline & $(n=27)$ & Par j 1-Par j 2 & $0.440^{*}$ & 1.000 & -0.236 & -0.260 & -0.137 & 0.044 & 0.195 \\
\hline & & PM 10 & 0.350 & $0.446^{* *}$ & -0.081 & -0.112 & -0.209 & -0.0255 & -0.075 \\
\hline & & PM 2.5 & $0.449^{*}$ & $0.995^{*}$ & -0.249 & -0.268 & -0.119 & 0.068 & 0.205 \\
\hline \multirow{8}{*}{$\begin{array}{l}\frac{\pi}{0} \\
\frac{\pi}{\pi} \\
\frac{\pi}{0}\end{array}$} & 2006 & Urticaceae Pollen & 1.000 & 0.094 & $-0.250^{* *}$ & $-0.369^{* *}$ & $-0.409^{* *}$ & -0.017 & 0.182 \\
\hline & $(n=150)$ & Par j 1-Par j 2 & 0.094 & 1.000 & $0.166^{*}$ & 0.147 & 0.130 & -0.156 & -0.054 \\
\hline & & PM 10 & 0.091 & $0.877^{* *}$ & $-0.195^{\star}$ & $-0.180^{*}$ & $-0.170^{*}$ & -0.121 & -0.091 \\
\hline & & PM 2.5 & 0.089 & $0.972^{*}$ & 0.0133 & 0.112 & 0.094 & -0.164 & -0.035 \\
\hline & MPC 2006 & Urticaceae Pollen & 1.000 & $0.283^{* *}$ & $0.515^{\text {** }}$ & $0.375^{* *}$ & 0.027 & $-0.388^{* *}$ & $0.458^{* *}$ \\
\hline & $(n=89)$ & Par j 1-Par j 2 & $0.283^{* *}$ & 1.000 & -0.067 & -0.091 & -0.144 & -0.087 & 0.055 \\
\hline & & PM 10 & 0.127 & $0.495^{\text {** }}$ & -0.196 & $-0.211^{\text {** }}$ & -0.162 & 0.086 & 0.069 \\
\hline & & PM 2.5 & $0.285^{\star *}$ & $0.985^{\text {** }}$ & -0.058 & -0.081 & -0.139 & -0.111 & 0.041 \\
\hline
\end{tabular}


Table 3. Par j 1-Par j 2 concentrations in different particle-size fractions (expressed as total sum allergens and percentages) in Córdoba and Granada.

\begin{tabular}{|c|c|c|c|c|c|c|c|c|c|c|}
\hline \multirow[b]{3}{*}{ Stage $(\mu \mathrm{m})$} & \multirow{2}{*}{\multicolumn{2}{|c|}{$\begin{array}{c}\text { Granada } \\
2006 \\
\text { (1st Feb-30th June) }\end{array}$}} & \multicolumn{8}{|c|}{ Córdoba } \\
\hline & & & \multicolumn{2}{|c|}{$\begin{array}{c}2006 \\
\text { (1st Feb-30th May) }\end{array}$} & \multicolumn{2}{|c|}{$\begin{array}{c}2007 \\
\text { (1st Feb- 31st May) }\end{array}$} & \multicolumn{2}{|c|}{$\begin{array}{c}2008 \\
\text { (9th Jan- 28th June) } \\
\end{array}$} & \multicolumn{2}{|c|}{$\begin{array}{c}2009 \\
\text { (13th Jan- 1st June) }\end{array}$} \\
\hline & $\mathrm{ng} / \mathrm{m}^{3}$ & $\%$ & $\mathrm{ng} / \mathrm{m}^{3}$ & $\%$ & $\mathrm{ng} / \mathrm{m}^{3}$ & $\%$ & $\mathrm{ng} / \mathrm{m}^{3}$ & $\%$ & $\mathrm{ng} / \mathrm{m}^{3}$ & $\%$ \\
\hline $1(\geq 5.8)$ & 2011.1 & 9.5 & 840.4 & 6.2 & 2337.4 & 10.2 & 961.5 & 7.4 & 1597.5 & 8.5 \\
\hline $2(<5.8-4.7)$ & 2608.5 & 12.4 & 1800.9 & 13.4 & 3633.8 & 15.8 & 2336.9 & 17.9 & 6638.3 & 35.2 \\
\hline $3(<4.7-3.3)$ & 1310.0 & 6.2 & 3380.5 & 25.1 & 4028.8 & 17.5 & 2494.8 & 19.1 & 3223.2 & 17.1 \\
\hline $4(<3.3-2.1)$ & 3496.4 & 16.6 & 2544.1 & 18.9 & 3496.0 & 15.2 & 2729.4 & 20.9 & 2679.9 & 14.2 \\
\hline $5(<2.1-1.1)$ & 4212.6 & 19.9 & 2474.7 & 18.4 & 3123.9 & 13.6 & 3276.6 & 25.1 & 2431.4 & 12.9 \\
\hline $6(<1.1)$ & 7508.5 & 35.6 & 2419.0 & 18.0 & 6396.9 & 27.8 & 2840.3 & 21.8 & 2314.1 & 12.3 \\
\hline PM 10 & 5929.5 & 28.1 & 6021.9 & 44.7 & 10000.0 & 43.4 & 5793.2 & 44.4 & 11459.0 & 60.7 \\
\hline PM 2.5 & 15217.5 & 72.1 & 7437.8 & 55.3 & 13016.9 & 56.6 & 8846.4 & 67.9 & 7425.3 & 39.3 \\
\hline TOTAL & 21116.6 & 100.0 & 13459.6 & 100.0 & 23016.9 & 100.0 & 13037.8 & 100.0 & 18884.4 & 100.0 \\
\hline
\end{tabular}




\section{a)}

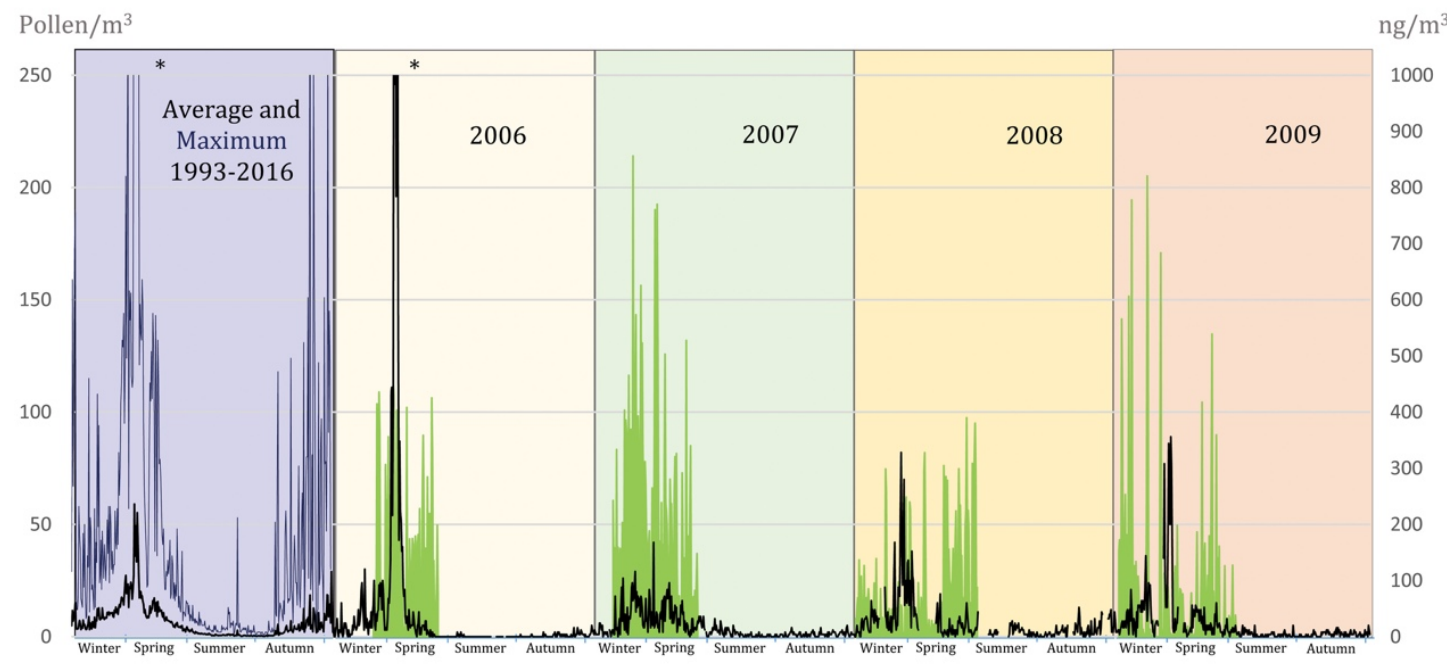

b)

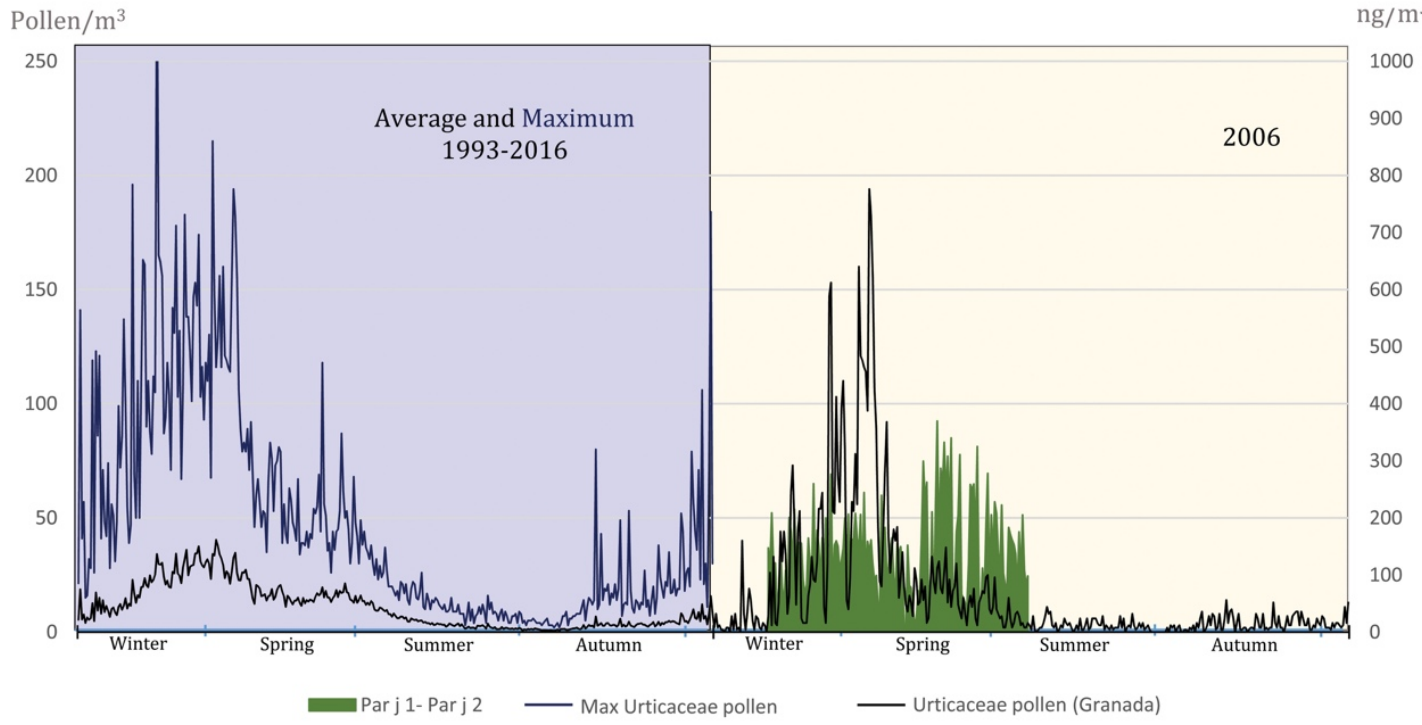

Figure 1. Annual dynamic of Urticaceae pollen (daily concentration during studied period and average and maximum concentrations (1993-2016) expressed in pollen/ $\left./ \mathrm{m}^{3}\right)$ and dynamic of Par j 1- Par j $2\left(\mathrm{ng} / \mathrm{m}^{3}\right)$ in Córdoba (a) and Granada (b). * Urticaceae pollen $=400 \mathrm{pollen} / \mathrm{m}^{3}$. 